\title{
摩擦圧接したオーステナイト系ステンレス鋼同径中実丸棒継手の 継手性能に及ぼす接合端面の傾きの影響とその許容限界*
}

\begin{abstract}
木村 真晃**，日下 正広**，海津 浩一***
Effect of Inclination of Weld Faying Surface on Joint Strength of Friction Welded Joint and its allowable limit for Austenitic Stainless Steel Solid Bar Similar Diameter Combination*

by KIMURA Masaaki**, KUSAKA Masahiro** and KAIZU Koichi***

This paper describes the effect of the inclination of the weld faying surface on joint strength of friction welded joint and its allowable limit for austenitic stainless steel (SUS304) solid bar similar diameter combination. In this case, the specimen was prepared with the inclination of the weld faying surface pursuant to the JIS Z 3607 , and the joint was made with that diameter of $12 \mathrm{~mm}$, a friction speed of $27.5 \mathrm{~s}^{-1}$, and a friction pressure of 30MPa. The initial peak torque decreased with increasing inclination of the weld faying surface, and then the elapsed time for the initial peak increased with increasing that inclination. However, the steady torque was kept constant in spite of the inclination of the weld faying surface increasing. The joints without the inclination of the weld faying surface, which were made with friction times of 1.5 and $2.0 \mathrm{~s}$ with a forge pressure of $270 \mathrm{MPa}$, had achieved $100 \%$ joint efficiency with the base metal fracture. Those joints had 90 degrees bend ductility with no crack at the weld interface. The joints with the inclination of the weld faying surface of $0.3 \mathrm{~mm}$ (gap length of $0.6 \mathrm{~mm}$ ), which were allowable distance, was also obtained the same result with this condition. Furthermore, those joints with a friction time of $2.5 \mathrm{~s}$ were obtained the same result. On the other hand, the joints with the inclination of the weld faying surface of $0.6 \mathrm{~mm}$ (gap length of $1.2 \mathrm{~mm}$ ), which was twice inclination of the allowable distance, were also obtained the same result in a friction time of $2.5 \mathrm{~s}$. However, the joints without the inclination of the weld faying surface at this friction time were not obtained the base metal fracture, although those achieved $100 \%$ joint efficiency. In conclusion, to obtain $100 \%$ joint efficiency and the base metal fracture with no cracking at the weld interface, the joint must be made with the inclination of the weld faying surface, which was allowable distance pursuant to the JIS Z 3607.
\end{abstract}

Key Words: Friction welding, Austenitic stainless steel, Solid bar, Similar diameter, Weld Faying Surface, Inclination, Joint Strength

\section{1. 緒}

\section{言}

摩擦圧接の場合，接合部にあたる接合端面（接合面）は， 一般には組み合わせる部材の回転軸に対して垂直であるこ とが望ましい，その理由として，圧接条件を新たに選定す る際には，接合端面を回転軸に対して垂直という理想状態 で調べるのが望ましいこと，一部の組み合わせでは異なる ものの接合する素材の強度差が大きな異材継手を作製する 場合, 高強度側の接合端面は接合後でもほぼそのままの状 態を保ったままで継手の圧接面に残存していると考えられ るため, 接合端面の傾きが得られる継手強度に対して影響 を及ぼす可能性があることなどが挙げられる。このため, 摩擦圧接に関する研究は数多くあるものの, 著者らを含め, その多くが回転軸に対して垂直である理想的な接合端面へ と加工して検討が行われている，ところで, 摩擦圧接法は

\footnotetext{
*受付日平成27年 1 月 9 日 受理日 平成27年 3 月 5 日 平 成26年12月溶接構造シンポジウム2014で発表

**正員兵庫県立大学大学院工学研究科 Member, Graduate School of Engineering, University of Hyogo

**** 兵庫県立大学大学院工学研究科 Graduate School of Engineering, University of Hyogo
}

自動化が容易，再現性が極めて高いことから得られる継手 の機械的特性は圧接条件によりほぼ一義的に決定できるな どの特徵を有していることでも知られている．また，摩擦 圧接品の実際の作業工程を考えると, 軸心に対してある程 度の傾きを持った状態の接合端面を有する部材を用いて接 合することも想定され，実際の作業現場からはそのような 要求も多い. したがって，ある程度の傾きを有したままで 接合することが可能となれば，切断したままの状態で接合 できることにもつながるため, 接合部材の前加工が容易も しくは不要となることから作業工程の短縮化を望むことが できる。それにより作業効率も向上させることができ，か つコストダウンも図れるため, 経済的にも有利に働くと考 えられる，すなわち，ある程度の接合端面の傾きを有する 部材を用いたときの継手性能を調査することはとても有益 である。

上述したような接合端面に傾きを有する部材の摩擦圧接 に関しては，炭素鋼同士の組み合わせについて JIS Z 3607 に より規定されている ${ }^{1)}$. その一部を Fig. 1 に示す. 同径中実丸 棒同士の場合，接合端面の傾き，すなわち接合部材の最長 部と最短部との差が $0.08 \sqrt{d}$ 以下であれば許容可能である， つまり，母材部から破断するような良好な継手を得ること ができると示されている。しかし，摩擦圧接法は異材継手 
の作製についてはもちろんのこと, 炭素鋼同士をはじめと する鉄鋼材料同士， $\mathrm{Al}$ 系材料同士，ステンレス鋼同士とい った同種材継手の作製においても多く利用されている.こ のうち, $\mathrm{Al}$ 系材料同士については接合端面の傾きの影響が 調査されているものの ${ }^{2)}$, 鉄鋼材料同士や $\mathrm{Al}$ 系材料同士の 継手と同様に多くの産業分野で用いられているステンレス 鋼同士に関する論文は, 著者らの知る限り見当たらない. また，実際の作業現場では，ステンレス鋼同士は炭素鋼同 士の場合と“ほほ同様”の圧接条件で母材部から破断する 継手が得られると言われている。しかし，前述したJIS 規 格 ${ }^{1)}$ にはステンレス鋼同士の接合においてもこの規格が適用 できるということは記されていない.さらに，ステンレス 鋼同士の摩擦圧接に関する報告は多いものの ${ }^{4-12)}$, ステン レス鋼同士は炭素鋼同士と “ほぼ同様” の圧接条件で接合 可能であるという報告も見受けられない.すなわち, 炭素 鋼同士とステンレス鋼同士では, 接合端面に傾きがない組 み合わせについても圧接条件が異なる可能性が十分に考え

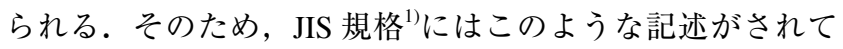
おらず, Fig. 1 に示した許容寸法も含め, 実際の作業現場など ではこれまでの経験則に基づいてそのような傾きを決定し たのではないかと推測することができる。したがって，ス テンレス鋼同士について，上述したような接合端面に種々 の傾きを施した試験片を用いて摩擦圧接を実施し, その摩 擦圧接現象を詳細に観察するとともに得られる継手強度を 調べ，どの範囲までの接合端面の傾きが許容可能であるか, つまりその許容限界を示すことは, 実際の作業現場などで は極めて有用であると考えられる.

そこで本研究では, ステンレス鋼摩擦圧接の継手性能に 及ぼす接合端面の傾きの影響を明らかにするため，オース テナイト系ステンレス鋼の代表格である SUS304 の同径中 実丸棒同士の組み合わせを取り上げ，JIS Z 3607 の炭素鋼の 摩擦圧接作業標準 ${ }^{1)}$ において示されている接合端面の傾きに 基づいてそれを種々変化させて接合実験を行った. そして, 摩擦過程中の接合現象を詳細に観察するとともに得られた 継手に対して引張試験などを実施することで, 継手性能に 及ぼす接合端面の傾きの影響を明らかにした，また，接合 端面が軸心に対して傾きを有さない理想的な接合端面の場 合の実験結果と比較することで, その傾きが許容できる範 囲を実験的に調べた.

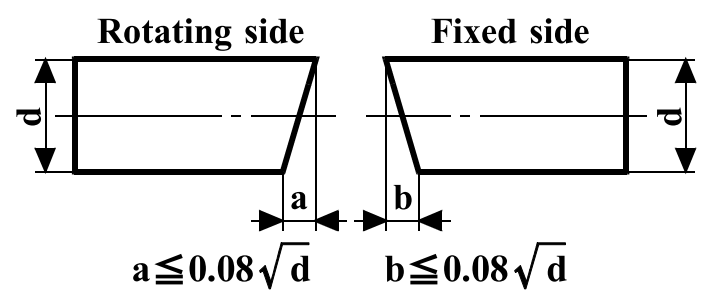

Fig. 1 Allowable inclination of weld faying surface for carbon steel friction welding specimens by JIS Z 3607 .

\section{2. 供試材料および実験方法}

\section{1 供試材料および試験片形状}

供試材料には，市販されている外径 $16 \mathrm{~mm}$ のSUS304 の 丸棒を用いた。 なお，本研究では供試材料に 2 種類の素材 を用いたが，これはそれらの入手時期が異なるためである. また，これら素材の引張強さは $682 \mathrm{MPa}$ および $670 \mathrm{MPa}$ で ある。これらを Fig. 2 に示すように接合端面直径が $\phi 12 \mathrm{~mm}$ となるように旋盤加工を施し，チャック内での回転を防止 するためにつかみ部の 3 方向を平削加工した形状を準備し た。そして，接合端面に対して傾きを有さない理想的な形 状 $(\mathrm{Gap}=0 \mathrm{~mm})$ と, Fig. 1 に示したようにJIS 規格 ${ }^{1)} に よ り$ 提 示されている接合端面の直径に対する傾きに準拠し，この 直径 $(\phi 12 \mathrm{~mm})$ に対して最大の Gap を有する傾き形状 $(\mathrm{Gap}=0.3 \mathrm{~mm})$ ，その 2 倍の Gap を有する傾き形状 $(\mathrm{Gap}=0.6 \mathrm{~mm})$ というように，接合端面の傾きを平面研削 盤による研削加工を施すことによって 3 種類の形状を作製 し，いずれも算術平均粗さを $0.05 \sim 0.15 \mu \mathrm{m}$ の範囲に仕上げ てそれぞれの試験片とした，そして，接合直前に接合端面 をアセトンにより脱脂してから接合実験に供した。

\section{2 実験方法}

接合にはブレーキ式摩擦圧接機を用いた。なお，摩擦時 間の影響を明瞭にするため, 継手へのブレーキ時の変形を 除去しなければならない。そこで，電磁クラッチを用い， 任意の摩擦時間終了と同時に固定側と回転側とを同速回転 させることで圧接面の相対速度を零とする方法 ${ }^{3)}$ で接合を行 った。そして，実験では， Gap $=0 \mathrm{~mm}$ 同士， Gap $=0.3 \mathrm{~mm}$ 同 士, Gap=0.6 mm 同士というように同じ傾きを有する試験片 をそれぞれ組み合わせ, 摩擦速度 $27.5 \mathrm{~s}^{-1}(1650 \mathrm{rpm})$, 摩擦 圧力 $30 \mathrm{MPa}$ の一定とし, 継手性能に大きく影響を及ぼす摩 擦時間とアプセット圧力を種々変化させて継手を作製した. そして, 摩擦圧接中の母材の様相をディジタルビデオカメ ラで撮影し, 摩擦トルクをサンプリング時間 $0.001 \mathrm{~s}$ として $\mathrm{A} / \mathrm{D}$ 変換ボードを介してパソコンに記録した。接合後，継 手の外観観察を行うとともに，圧接面から排出したばりを 除去して平行部長さ $60 \mathrm{~mm}$ の引張試験片へと加工して継手 の引張試験を行った.さらに，このような加工を行った後 にチャックのつかみ部も除去した一様丸棒である曲げ試験

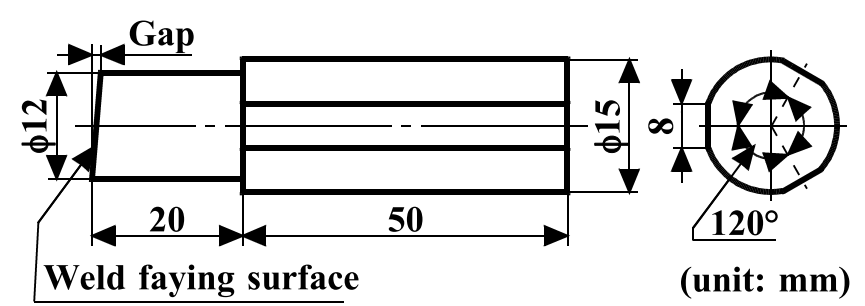

Fig. 2 Shape and dimension of friction welding specimen. 
片へと加工し，圧接面に荷重が作用するようにして継手の 3 点曲げ試験を実施することで継手の変形能を評価した。い ずれの試験でも油圧式万能試験機を用い, 各試験は室温に て行った。なお，後述するが，摩擦時間によっては十分な ばりが排出せずに圧接面に傾きが未接合部としてそのまま 残る場合がある。しかし，本研究ではこのような圧接面に 残存した傾きを除去せずにばりのみを取り除いて引張試験 片へと加工して引張試験を実施している。また，摩擦時間 が短い場合，回転側と固定側とが食い違うことによる軸心 の不一致，すなわち回転中心のズレを生じる可能性がある が，このような回転中心のズレに起因して継手の引張強さ に差異を生じることがないことを確認している.さらに， 得られた継手の圧接面から固定側の軸方向へそれぞれ約 $10 \mathrm{~mm}$ 離れた位置で切断した後に圧接面に垂直な軸方向で かつ圧接面の中心線である軸心部を通る面で切断を行い, 観 察面にバフ研磨を施した後にヴィレラ液を用いてエッチン グすることで圧接面近傍断面のマクロ観察を行った。また， 断面マクロ観察用の試料を用い, 圧接面を垂直に横切る軸 心部と外表面の中心である $1 / 2 \mathrm{R}$ 部の軸方向線上の硬さ分布 の測定を行った。なお，本報告では， Gap $=0 \mathrm{~mm}$ 同士を組み 合わせて作製した継手を GL00 継手, Gap=0.3 mm 同士のそれ を GL06 継手，Gap=0.6 mm 同士のそれを GL12 継手と，接合 端面間の最大 Gap の総量でそれぞれの組み合わせを記す.

\section{3. 実験結果および考察}

\section{1 理想的な接合端面の傾き（GLO0 継手）の場合}

継手性能に及ぼす接合端面の傾きの影響を明らかにする ためには，その傾きを有さない場合，すなわち回転軸に対 して垂直となる理想状態での継手性能を明らかにする必要 がある。しかし，前述したようにステンレス鋼同士は炭素 鋼同士と“ほほ同様”の圧接条件で接合可能であるという
報告は著者らの知る限りでは見受けられない。また，ステ ンレス鋼同士の摩擦圧接に関しては，これまでに様々な検 討が行われているが4-12)，いずれの場合も接合端面の直径 や圧接条件が異なることから統計的な比較を行うことが困 難となっている.そこで本節では, Fig. 2 に示した試験片形状 うち，傾きを有さない $\mathrm{Gap}=0 \mathrm{~mm}$ 同士の組み合わせについ て，摩擦速度と摩擦圧力とを一定条件として摩擦過程中の 接合現象を観察し，得られる継手の引張強さを調べること で母材部から破断する圧接条件を探った。

\subsection{1接合現象と継手強度に及ぼす摩擦時間の影響}

(a) 摩擦過程中の母材様相と摩擦卜ルク

$\mathrm{Gap}=0 \mathrm{~mm}$ 同士，すなわち GL00 継手の摩擦過程中の母材 外観の一例を Fig. 3 (a) に，摩擦トルク曲線の一例を Fig. 3 (b) にそれぞれ示す. なお，Fig. 3 (a) の 1)〜6) はFig. 3 (b) の (1)〜(6) にそれぞれ対応している，1) は接合端面同士が接触 した瞬間であり，この直後から摩擦トルクは急上昇して (2) となり，その直後は (3) のように摩擦トルクがほぼ一定值を 示した. また，この間の母材様相を見ると，2)や3)の写真の ように1)とあまり差異は認められなかった。そして, 圧接面 で焼付きを生じることにより摩擦トルクが再び急上昇して 摩擦時間が約 $0.9 \mathrm{~s}$ で (4) の約 $25 \mathrm{Nm}$ の初期トルクに達し, こ のあたりから4)のように圧接面では変形を生じ，5) のよう に多少の火花を散らしながら接合された。その後，摩擦卜 ルクは減少して (6) のように約 $5 \mathrm{Nm}$ でほぼ一定值を示す定 常トルク域となり，6) のように圧接面からばりを排出して大 きく変形をともないながら接合された。なお，同じ圧接条 件で接合した同径の軟鋼同士の結果 ${ }^{3)}$ と比較すると，母材様 相はほぼ同じような変化を示した。一方，摩擦トルク曲線 においては，ほぼ一定值を示す擦れ過程と急上昇して初期 トルクに到達する焼付過程とに分けることができたが，初 期トルクの值およびその到達時間は異なっており，軟鋼同 士の場合よりも短い時間で初期トルクへと到達しているこ

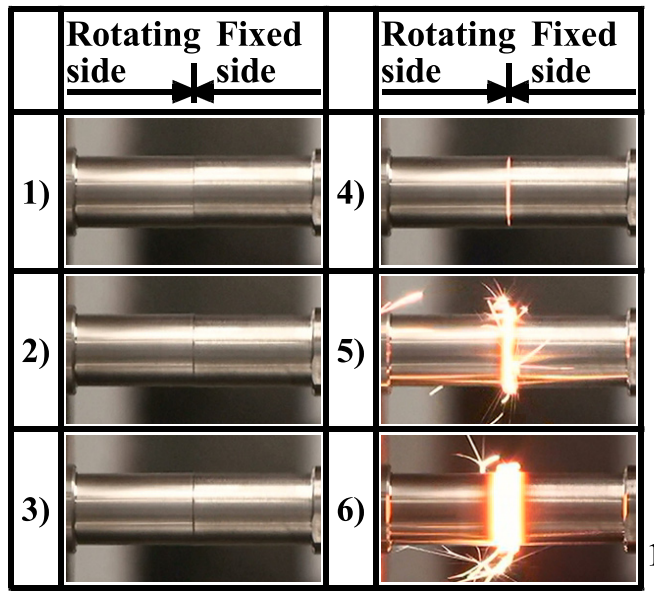

(a) Joining behavior

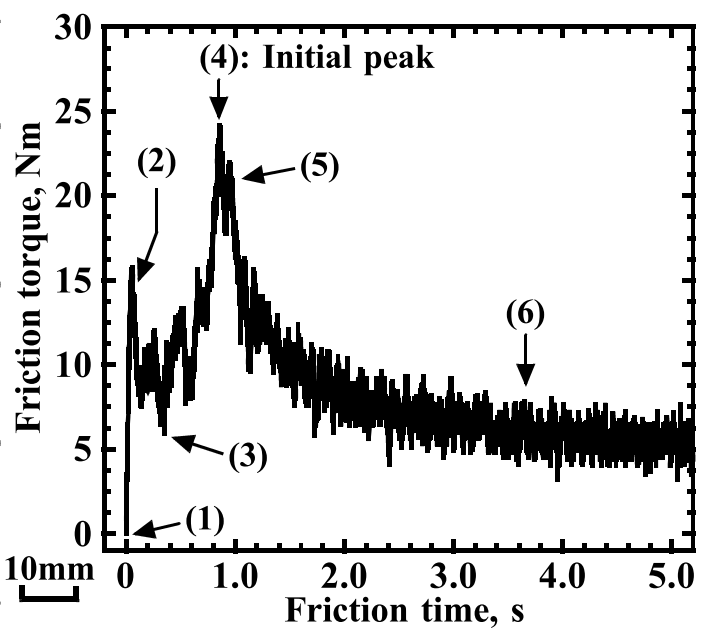

(b) Friction torque curve

Fig. 3 Joining behavior and friction torque curve during friction process of GL00 joint. 
とがわかった。

(b) 継手強度に及ぼす摩擦時間の影響

種々の摩擦時間で継手を作製してそれらの引張試験を行 った. 得られた引張強さを母材の引張強さとの比として求 めた継手効率を Fig. 3 (b) に示した摩擦トルク曲線上にプロ ットして Fig. 4 に, 引張試験後の継手の外観写真の一例を Fig. 5 にそれぞれ示す.なお,アプセット圧力は摩擦圧力と同 じ $30 \mathrm{MPa}$ とした結果である. Fig. 4 を見ると, 摩擦時間の増 加にともなって継手効率は増加し，初期トルク付近の摩擦

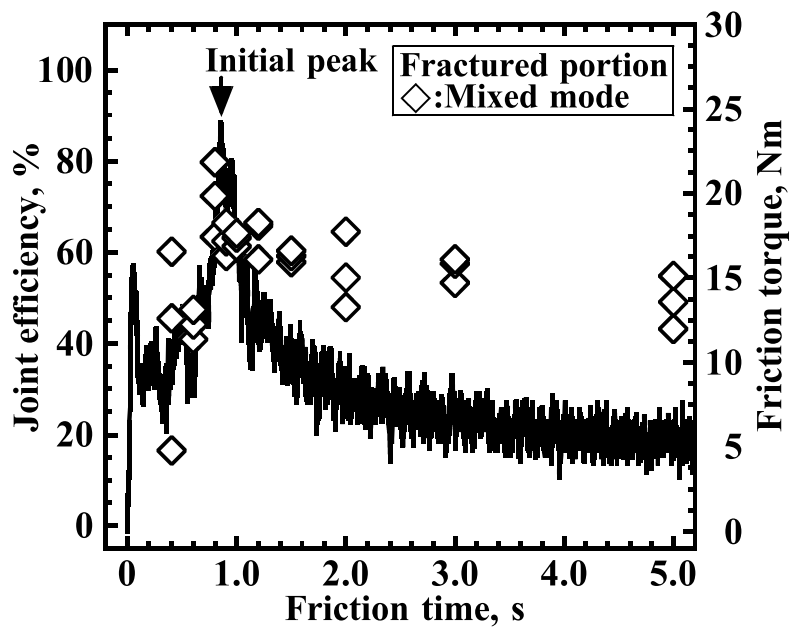

Fig. 4 Relationship between friction time and joint efficiency of GL00 joint, in relation to friction torque; forge pressure of $30 \mathrm{MPa}$.

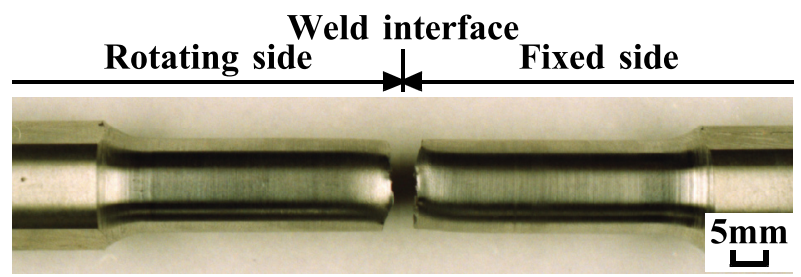

Fig. 5 Example of appearance of joint tensile tested specimen with mixed mode fracture.
時間で $70 \%$ 前後と最大となった。 その後, 摩擦時間の増加 にともなって継手効率は減少して $40 \%$ 前後とほぼ一定值を 示した。また，継手はすべて Fig. 5 に示すように母材部と圧 接面とにまたがる混合破断を呈した。よって，アプセット 圧力が摩擦圧力と同じ条件では良好な継手を得ることはで きなかった。また，この結果は同径の軟鋼同士の場合 ${ }^{13)}$ と は異なることもわかった。

母材部から破断する継手が得られなかった原因を調べる ため，継手の圧接面近傍断面の観察を行った。その一例と して，摩擦時間 $1.2 \mathrm{~s} ， 2.0 \mathrm{~s} ， 5.0 \mathrm{~s}$ のときの結果を Fig. 6 に示 す.アプセット圧力が摩擦圧力と同じ $30 \mathrm{MPa}$ の場合では, いずれの摩擦時間においても Fig. 6 の矢印で示すように圧 接面に未接合部が認められた。また, 未接合部は (a)に示した ように摩擦トルクが初期トルクに到達した後の摩擦時間 $1.2 \mathrm{~s}$ の継手が最も小さく，摩擦時間の増加にともなって未 接合部が増加して (c) に示した摩擦時間 $5.0 \mathrm{~s}$ の継手が最も 多かった。これらより，このような未接合部が圧接面に存 在していいたために，アプセット圧力 $30 \mathrm{MPa}$ で接合した継 手は母材部から破断しなかったことがわかった。なお，摩 擦時間が長くなると未接合部が増加する理由としては，摩 擦トルクが初期トルクに到達した以降では圧接面の特に外 周部において結合一変形一破壊という結合分離を繰り返し ており，摩擦時間の経過にともなってこの結合分離領域が 増加することが蓮井ら ${ }^{14)} に よ り$ 示されている.すなわち， 長い摩擦時間では圧接面に結合分離部が存在していること を意味している。よって，結合分離部が未接合部として圧 接面に存在しており，摩擦時間が長くなるとその未接合部 も増加したためと考えられる。なお，このような未接合部 が増加したために初期トルク到達以降の摩擦卜ルクも低下 して定常トルク域へと到達している現象とも一致する。ち なみに，このような摩擦時間の増加にともなう未接合部領 域の増加は，同じ圧接条件で接合した同径の軟鋼同士 ${ }^{3)}$ $\mathrm{Al}$ 合金同士 ${ }^{15)}$ の場合でも観察された.

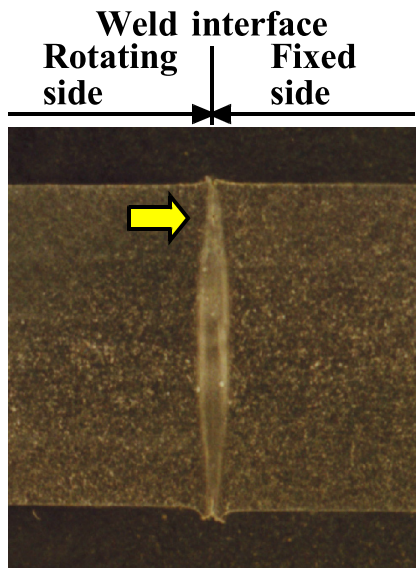

(a) $1.2 \mathrm{~s}$

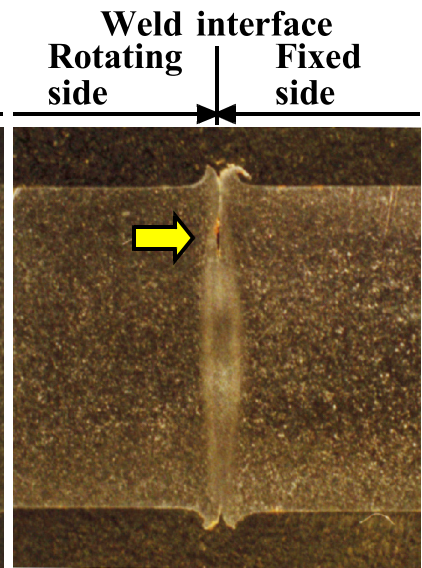

(b) $2.0 \mathrm{~s}$

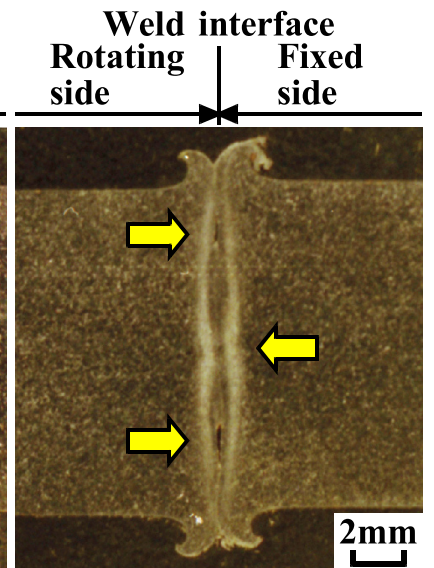

(c) $5.0 \mathrm{~s}$

Fig. 6 Cross-sectional appearances of weld interface region of GL00 joint at various friction times; forge pressure of 30MPa. 


\subsection{2 継手強度に及ぼすアプセット圧カの影響}

Fig. 6 に示したような圧接面の未接合部を消失させて継手 強度の向上を図るため, 継手性能に大きく影響を及ぼすア プセット圧力を増加させて継手を作製した． 継手効率とア プセット圧力との関係を Fig. 7 に, 引張試験後の継手外観の
一例を Fig. 8 にそれぞれ示す. なお，デー夕は示していない が摩擦トルクが初期トルクに到達するよりも前の摩擦時間 では圧接面の全面が接合されていなかったことから，摩擦 トルクが初期トルクに到達した以降の摩擦時間を種々設定 して検討を行った.Fig. 7 (a) に示した摩擦時間 $1.2 \mathrm{~s}$ の結果
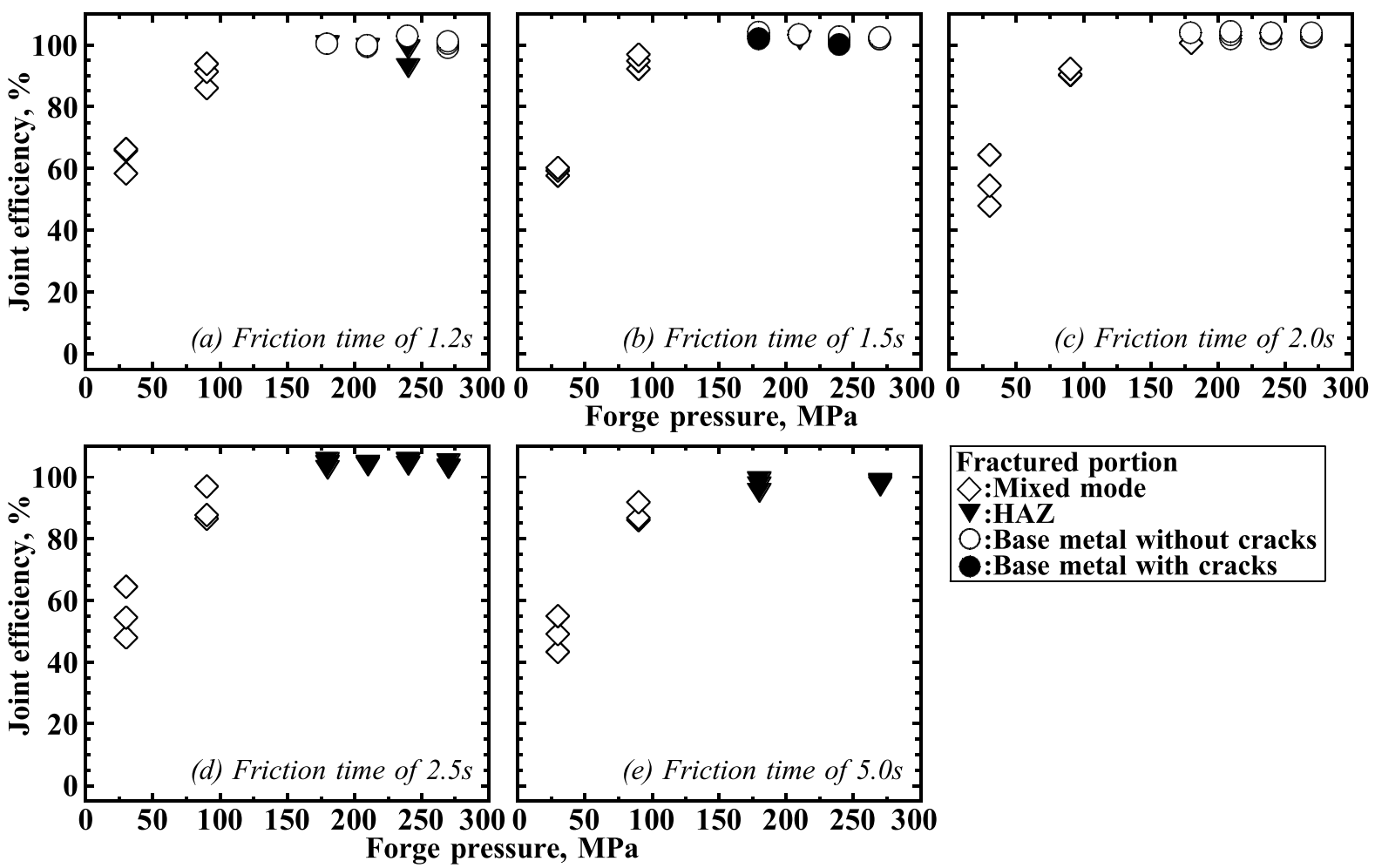

\section{Fractured portion $\diamond:$ Mixed mode $\nabla: H A Z$ \\ :Base metal without cracks \\ :Base metal with cracks}

Fig. 7 Relationship between forge pressure and joint efficiency at various friction times of GL00 joints

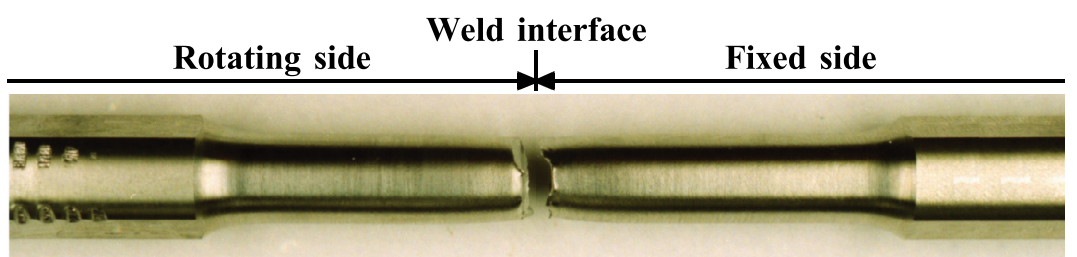

(a) Mixed mode fracture (remark: $\diamond)$

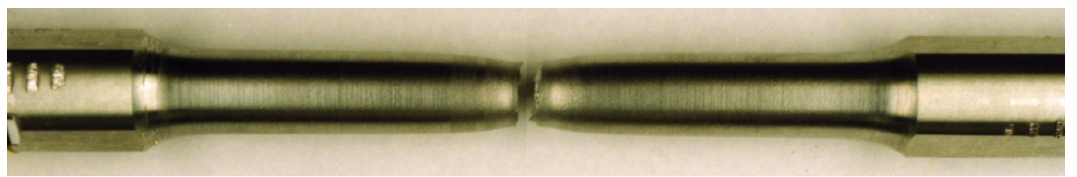

(b) HAZ fracture (remark: $\nabla$ )

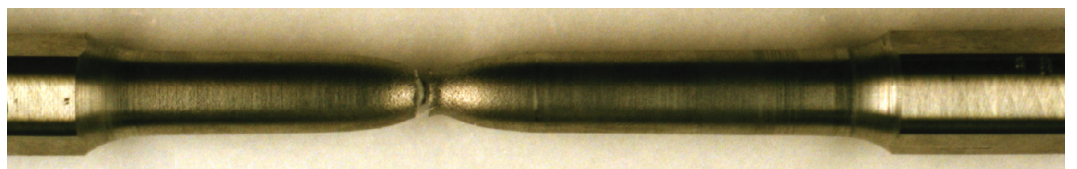

(c) Base metal fracture without cracks (remark: $\bigcirc$ )

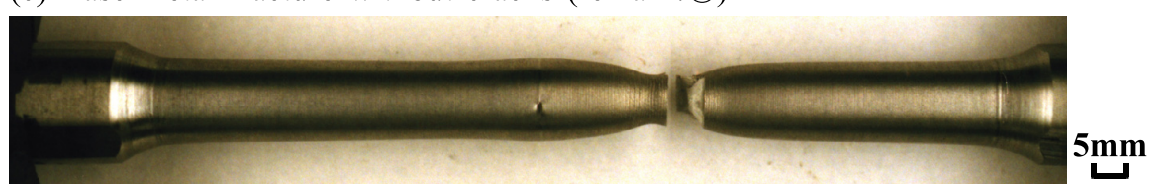

(d) Base metal fracture with cracks (remark:

Fig. 8 Examples of appearances of joint tensile tested specimens. 


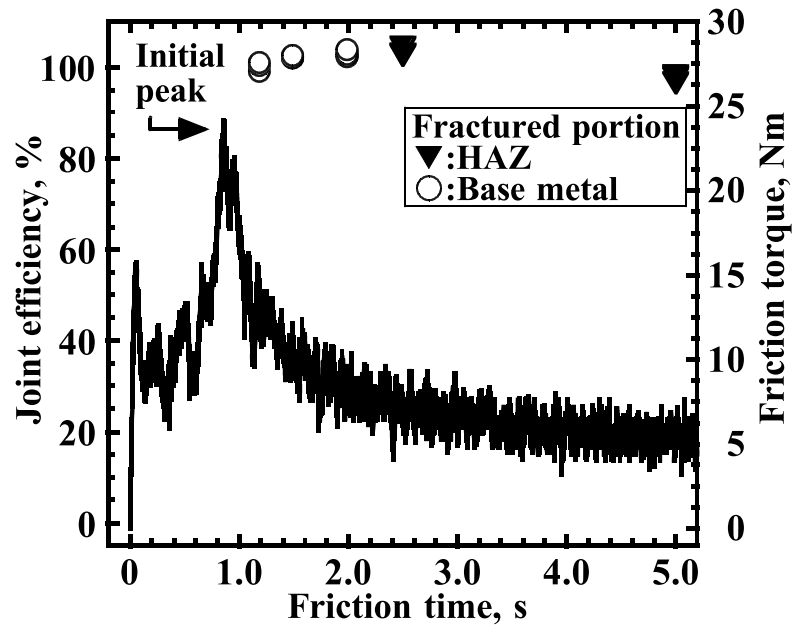

Fig. 9 Relationship between friction time and joint efficiency of GL00 joint, in relation to friction torque; forge pressure of $270 \mathrm{MPa}$

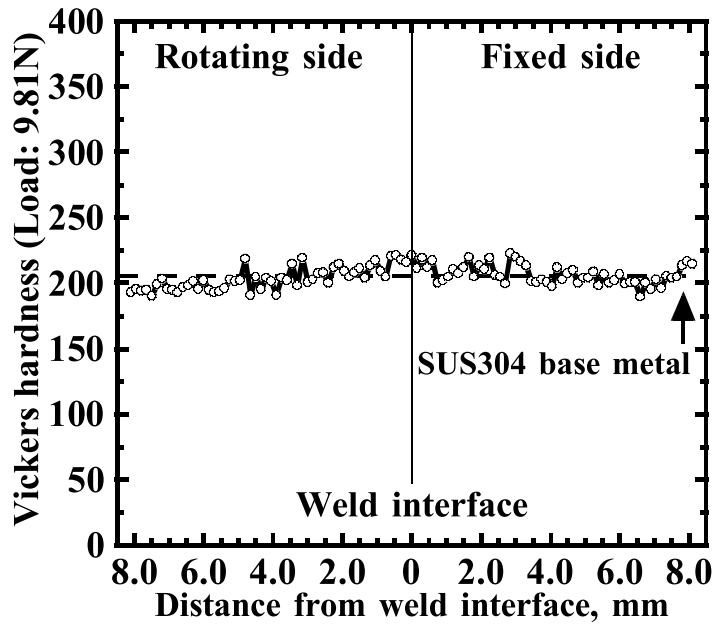

(a) Friction time of $1.2 \mathrm{~s}$

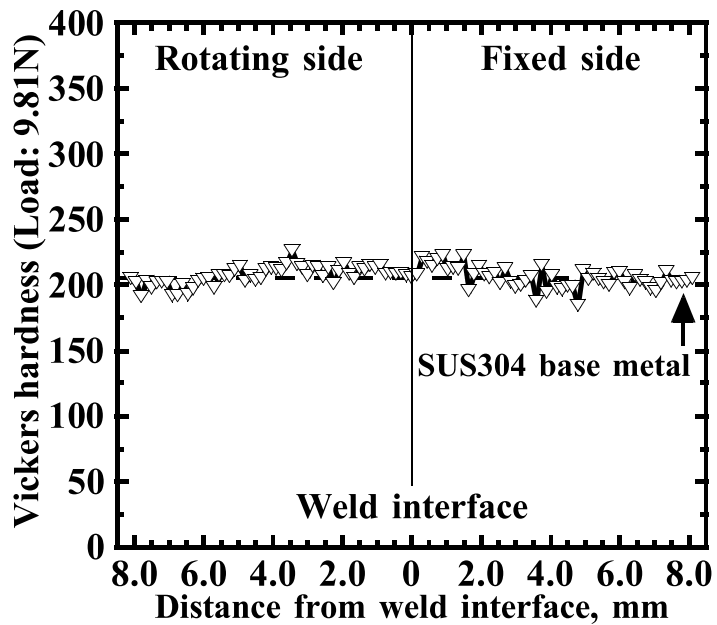

(b) Friction time of $5.0 \mathrm{~s}$

Fig. 10 Vickers hardness distribution across weld interface of joint; forge pressure of $270 \mathrm{MPa}$.
を見ると，アプセット圧力 $180 \mathrm{MPa}$ では 100\%の継手効率 を有して○印のように母材破断する継手も得られたが, $270 \mathrm{MPa}$ ではすべての継手が Fig. 8 (c) のように母材部から 破断した。また，引張試験後の継手外観を見ると，圧接面 にはき裂などの欠陥は観察されなかった. Fig. 7 (b) に示した 摩擦時間 $1.5 \mathrm{~s}$ の結果も同様にアプセット圧力 $180 \mathrm{MPa}$ 以上 で母材破断がいくつか得られ，270 MPaではすべて母材部 から破断した。また，アプセット圧力 $180 \mathrm{MPa} ， 240 \mathrm{MPa}$ の 条件で母材破断を呈した継手のうちの各 1 本については, 引 張試験後の継手を見ると Fig. 8 (d) に示すように圧接面には き裂が観察されたため，これらのアプセット圧力では良好 な継手が作製できたとは言い難い結果であった。さらに， Fig. 7 (c) に示した摩擦時間 $2.0 \mathrm{~s}$ ではアプセット圧力 $180 \mathrm{MPa}$ では一部の継手が母材破断しており，210 MPa 以上 では母材破断となった。そして, Fig.7 (d) に示した摩擦時間 $2.5 \mathrm{~s}$ と Fig. 7 (e) に示した摩擦時間 $5.0 \mathrm{~s}$ の結果を見ると, $180 \mathrm{MPa}$ 以上のアプセット圧力では継手効率 100\%を有して いるものの Fig. 8 (b) のように HAZ 部からの破断を呈して おり，母材破断するような良好な継手は得られなかった。 これらの結果より，摩擦圧力 $30 \mathrm{MPa}$ の場合，アプセット圧 力を $270 \mathrm{MPa}$ 付加したときに母材部から破断する良好な継 手を得られることがわかった。

アプセット压力を $270 \mathrm{MPa}$ とした場合の継手効率と摩擦 時間の関倸を整理して Fig. 9 に示す. Fig. 9 より, 継手は初期 トルク後の摩擦時間 1.2 2.0 s の範囲において母材破断とな っており，それょりも長い摩擦時間では継手効率はほぼ 100\%が得られるが，圧接面およびその近傍が摩擦熱の影響 を受けたことにより母材破断するような良好な継手は得る ことができなかった。つまり，母材破断する継手を得るた めには，摩擦時間 1.2 2.0 s の範囲が最適であると言える.

長い摩擦時間で HAZ 破断となった原因を探るため，圧接 面近傍断面の硬さ分布の測定を行った。一例として，摩擦 時間を $1.2 \mathrm{~s}$ と $5.0 \mathrm{~s}$ と設定したときの結果を Fig. 10 に示す. なお，どちらの継手もアプセット圧力は $270 \mathrm{MPa}$ として接 合した. Fig. 10 を見ると，どちらの摩擦時間でも圧接面近傍 およびその近傍は硬化して扔らず，ともに母材のそれとほ ぼ同じような硬さ分布を呈していた。よって，摩擦時間 $5.0 \mathrm{~s}$ において HAZ 破断した原因は，圧接面近傍の硬化では なく組織変化によるものであることが明らかとなった。な お，摩擦圧力 $30 \mathrm{MPa}$ の場合，同径の軟鋼同士ではアプセッ 卜圧力を増加させなくても母材破断する良好な継手が得ら れているため ${ }^{13)}$ ，この摩擦圧力のとき，SUS304 と軟鋼とで は母材破断する継手が得られる圧接条件が異なることもわ かった。

\section{2 最大傾きを有する接合端面（GL06 継手）の場合}

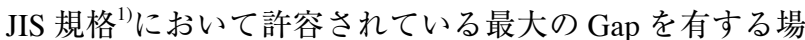
合，すなわち $\mathrm{Gap}=0.3 \mathrm{~mm}$ 同士（GL06 継手）の摩擦過程中 の母材外観と摩擦トルク曲線の一例を Fig. 11 に示す.なお, 


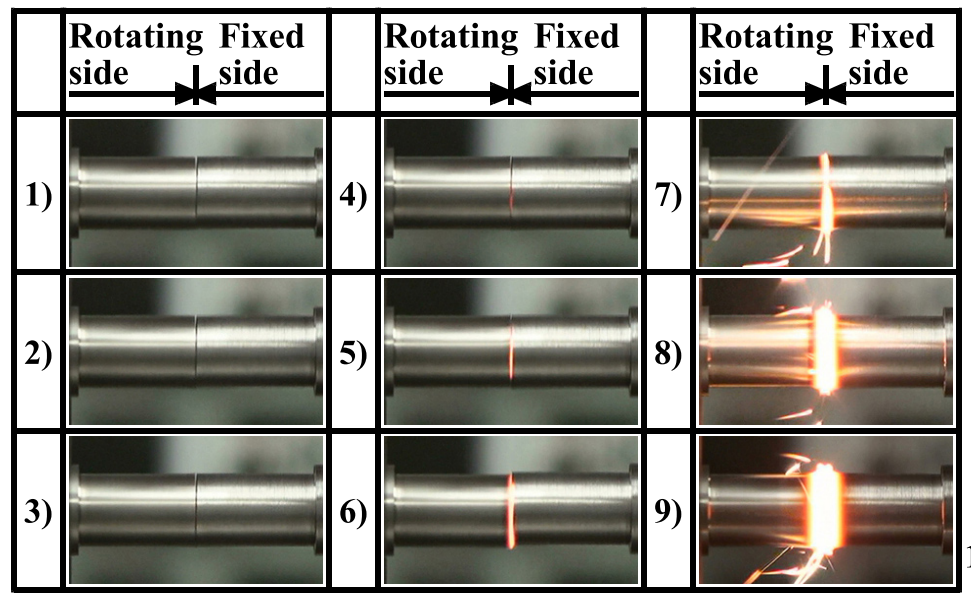

(a) Joining behavior

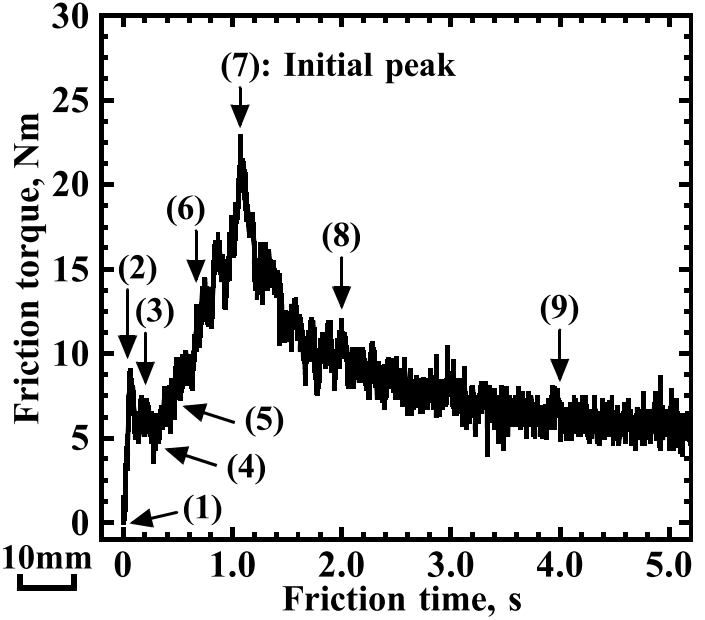

(b) Friction torque curve

Fig. 11 Joining behavior and friction torque curve during friction process of GL06 joint

実験では, 写真上方が Gap (Fig. 1 の図を上下逆さまとした状 態）となるように試験片を配して接合を行っており，Fig. 11 (a)の 1)〜9) は Fig. 11 (b)の (1)〜 (9)にそれぞれ対応して いる.1) は接合端面の先端にあたる試験片の最長部同士が接 触した瞬間であり，この直後から摩擦トルクは急上昇して (2) となり，そしてほぼ一定值を示す (3)〜 (5) のような擦れ 過程となった.この間の母材様相を見ると, 2)〜5)の写真に 示すように上方の Gap は完全には接触していない状態であ った.そして, (5) あたりから摩擦トルクが再び急上昇して5) 〜6)の写真に示すように回転側試験片と固定側試験片とが 上下方向に細かな振動をともないながら接合が進行し，摩 擦時間が約 $1.1 \mathrm{~s}$ で (7) の約 $23 \mathrm{Nm}$ の初期トルクに達した. ま た，このあたりから 7) の写真のように圧接面は変形を生じ て8)のように多少の火花を散らしながら接合され, その後, 摩擦トルクは減少して (9) のように約 $5 \mathrm{Nm}$ でほぼ一定值を 示し,9)のように圧接面からばりを排出して大きく変形しな がら接合された.さらに，5)～6) の写真に示したような回転 側試験片と固定側試験片との上下方向の細かな振動は，初 期トルク到達以降の摩擦時間ではほとんど観察されず，接 合後の継手にも回転側と固定側との回転中心のズレもほと んど認められなかった. Fig. 3 に示した GL00 継手の結果と 比較すると, 初期トルクに到達するまでの時間が長くなり, 初期トルクの值は小さくなった.

継手効率と摩擦時間との関係を Fig. 11 (b) に示した摩擦 トルク曲線上にプロットして Fig. 12 に示す。なお, Fig. 6 の 結果を踏まえ, Fig. 9 に示したように母材破断を得ることが できたアプセット圧力 $270 \mathrm{MPa}$ として継手を作製した. Fig. 12 を見ると, この継手の場合の初期トルク付近の摩擦時間 $1.2 \mathrm{~s}$ では 1 本が Fig. 8 (c) に示したような母材破断が得られ たが, 他は Fig. 8 (a)のような混合破断であった. また, 摩擦 時間 $1.4 \mathrm{~s}$ ではすべての継手が $100 \%$ を有してこのうちの 1 本が母材破断となったが，他は Fig. 8 (b) のような HAZ 破断 であった。そして，摩擦時間 $1.5 \mathrm{~s}$ ではすべての継手が母材

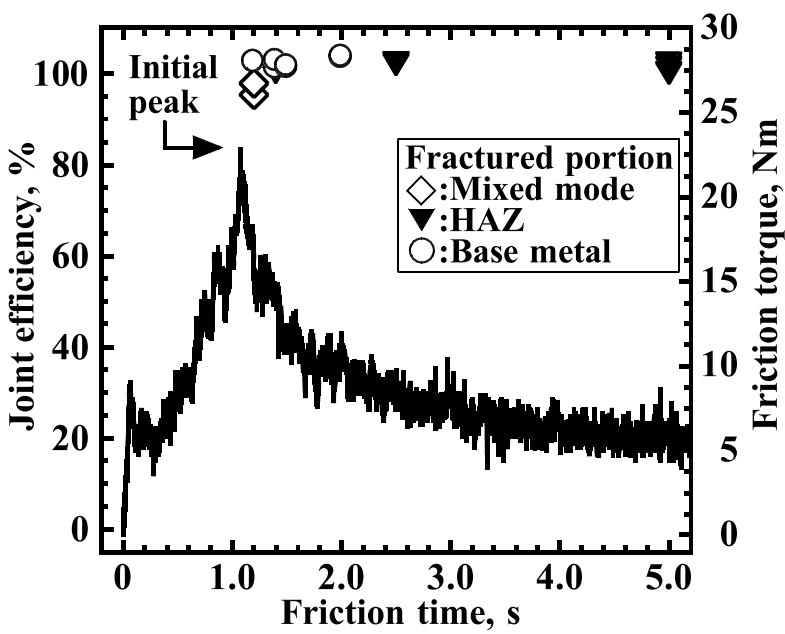

Fig. 12 Relationship between friction time and joint efficiency of GL06 joint, in relation to friction torque; forge pressure of $270 \mathrm{MPa}$.

破断を示し，2.0 s，2.5 s でも同様な結果が得られた。しか し，摩擦時間がさらに長い $2.5 \mathrm{~s}$ と $5.0 \mathrm{~s}$ では，得られた継手 強度に差異はないもののすべての継手が HAZ 破断となっ た。これらより，GL06 継手の場合は，Fig. 9 に示した GL00 継手の場合と母材破断する継手が得られる摩擦時間の範囲 が異なることがわかった。

\section{3 最大傾きの 2 倍の傾きを有する接合端面（GL12 継 手) の場合}

JIS 規格 ${ }^{1)} よ よ り$ 許容されている Gap の 2 倍を有する場 合，すなわち $\mathrm{Gap}=0.6 \mathrm{~mm}$ 同士 (GL12 継手) の摩擦過程中 の母材外観と摩擦トルク曲線の一例を Fig. 13 に示す.なお, この実験でも写真上方に Gap となるように接合試験片を配 しており,Fig. 13 (a)の 1)〜9) は Fig. 13 (b)の (1)〜(9)にそれ ぞれ対応する.1) は接合端面の先端同士が接触した瞬間であ り，この直後から摩擦トルクは急上昇して (2) となり，そし てほぼ一定值を示す (3)〜 (4)のような擦れ過程となった。こ 


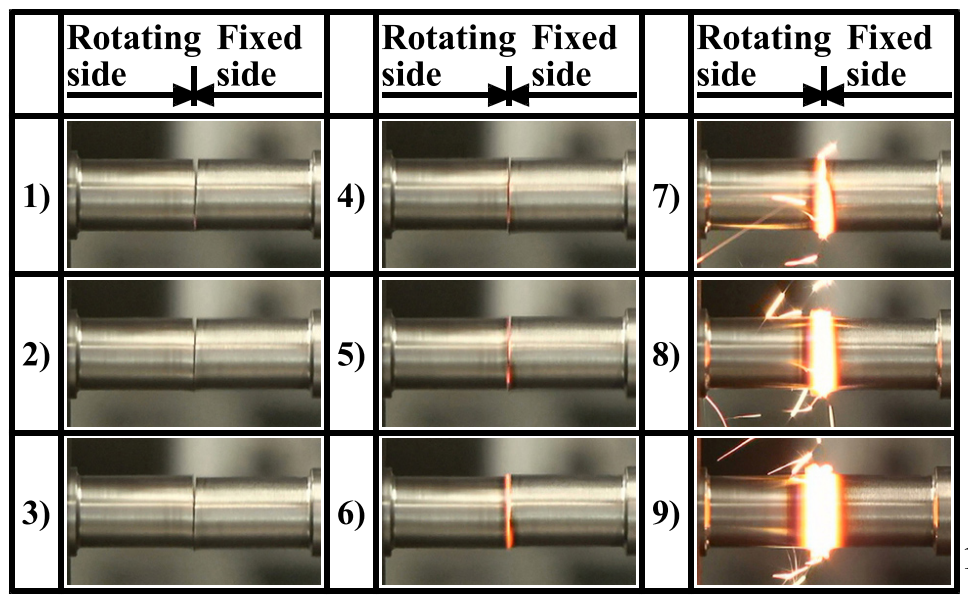

(a) Joining behavior

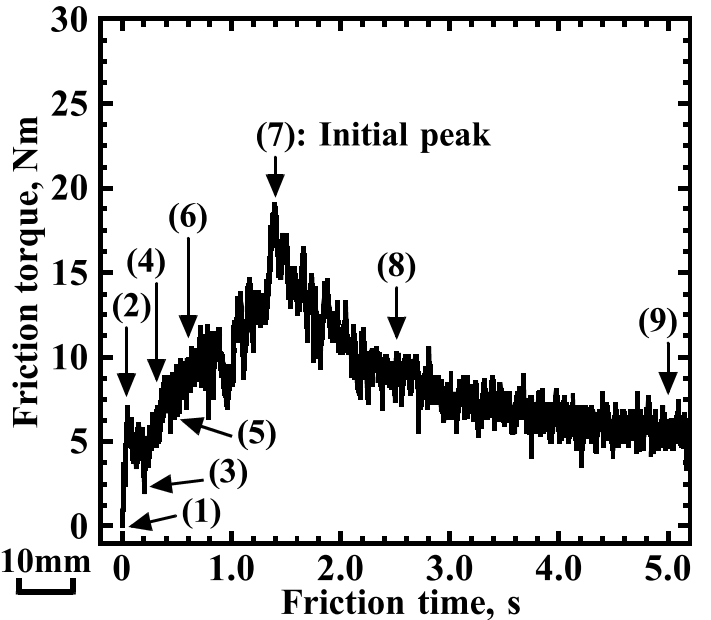

(b) Friction torque curve

Fig. 13 Joining behavior and friction torque curve during friction process of GL12 joint.

の間の母材様相を見ると, 2)〜4) の写真に示すように上方の Gap は完全には接触していない状態を呈しており，どちら の試験片も上下方向に細かな振動をともなっているのが明 瞭に観察された。また，このような上下方向の振動は， GL06 継手の場合よりもその振れ幅が大きいように観察され た.そして，(4) あたりから摩擦トルクが再び上昇して, 摩擦 時間が約 $1.4 \mathrm{~s}$ で (7) の約 $19 \mathrm{Nm}$ の初期トルクに達した.この あたりから 7) の写真のように圧接面の変形が大きくなって 8)のように多少の火花を散らしながら接合が進行し，その 後, 摩擦トルクは減少して (9) のように約 $5 \mathrm{Nm}$ でほぼ一定 值を保ち9)のように圧接面からばりを排出して大きく変形 をともないながら接合された。 さらに，この組み合わせで も回転側試験片と固定側試験片との上下方向の細かな振動 は，初期トルク到達以降の摩擦時間ではほとんど観察され ず，接合後の継手にも回転側と固定側との回転中心のズレ もほとんど認められなかった. また, Fig. 11 に示した GL06 継手の結果と比較すると, 初期トルクに到達するまでの時 間がさらに長くなり，初期トルクは小さくなった。

継手効率と摩擦時間との関係を Fig. 13 (b) に示した摩擦 トルク曲線上にプロットして Fig. 14 に示す.なお，この実験 でもFig. 9 に示した結果を踏まえてアプセット圧力は $270 \mathrm{MPa}$ とした. Fig. 14 を見ると, この継手の場合の初期卜 ルク到達前の摩擦時間 $1.2 \mathrm{~s}$ ではすべてが Fig. 8 (a) に示した ような混合破断を呈しており，継手効率もばらついた結果 であった。摩擦時間 $1.5 \mathrm{~s}$ でも $100 \%$ の継手効率は得られて おらず，それよりも少し長い摩擦時間である $1.7 \mathrm{~s}$ ，すなわ ち初期トルク付近のときに $100 \%$ の継手効率が得られた. ま た，このうちの 1 本は Fig. 8 (c) のような母材破断する継手 であったが，他はすべて混合破断であった。そして，摩擦 時間 $2.5 \mathrm{~s}$ ではすべての継手が母材破断となったが，摩擦時 間がさらに長い $5.0 \mathrm{~s}$ では得られた継手強度に差異はないも ののすべて HAZ 破断となった。これらより，GL12 継手の 場合, GL00 継手や GL06 継手とは母材部から破断する継手

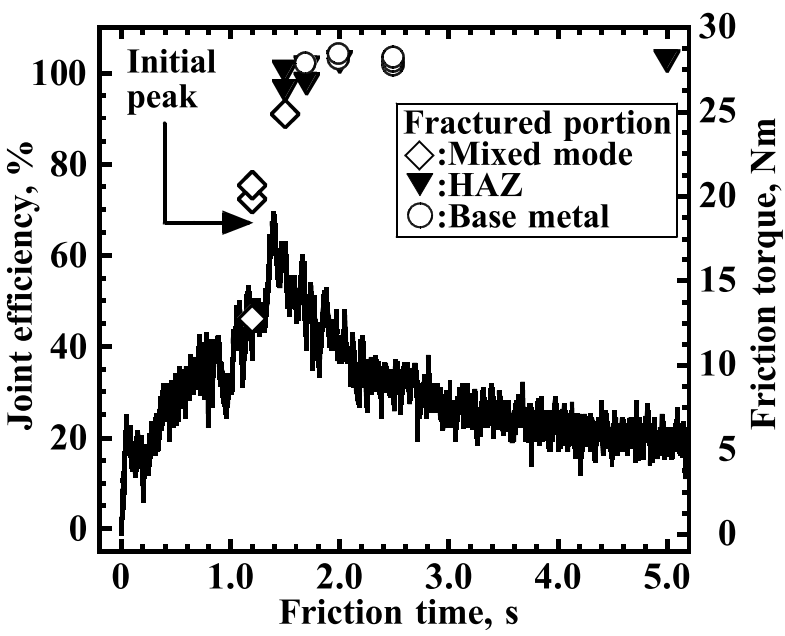

Fig. 14 Relationship between friction time and joint efficiency of GL12 joint, in relation to friction torque; forge pressure of $270 \mathrm{MPa}$.

が得られる摩擦時間の範囲が異なっており，接合端面の傾 きが大きくなるとそのような継手が得られる摩擦時間が長 くなることがわかった。

\section{4. 継手性能に及ぼす接合端面の傾きの影響}

本章では，接合端面の傾きが継手性能に及ぼす影響を明 らかにするため，前章までにおいて示した各継手の結果を 比較することによりその接合端面の傾きによって生じる隙 間，すなわち Fig. 15 に示すような接合端面間の最大 Gap 総 量である GL の距離が許容することができる範囲について 検討した。

\section{1 摩擦トルクの各パラメータの検討結果}

摩擦トルクに及ぼす接合端面の傾きの影響を明らかにす るため, Fig. 3 (b), Fig. 11 (b), Fig. 13 (b) に示した各継手の摩 


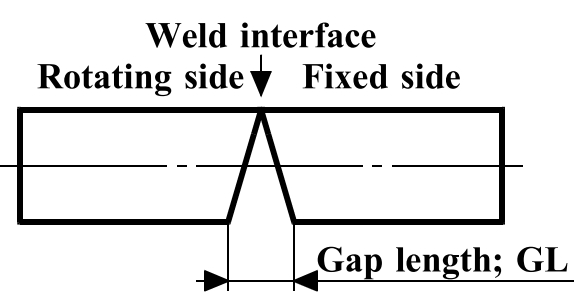

Fig. 15 Define of gap length in this study.

擦トルク曲線から初期トルクと定常トルクの各値を読みと った。それを，各接合端面の傾きごとに整理した結果を Fig. 16 (a) に，初期トルクに到達するまでに経過した摩擦時 間，すなわち初期トルク到達時間を同様に整理した結果を Fig. 16 (b)にそれぞれ示す.なお, 定常卜ルクについては, 摩 擦時間 10.0 sに扔ける值を参照した。 Fig. 16 (a) を見ると, 初 期卜ルクはGLの増加にともなって小さくなったが，定常 トルクには大きな変化は認められなかった。これは，以下 のように考えられる．接合端面の傾きが大きくなるほど初 期に接触する箇所も小さくなり，さらに接触している筒所 では摩擦熱による温度上昇にともなって母材の降伏強度が 低下するため，接合端面に傾きがある場合では初期に接触 した箇所から変形を生じ始めてばりを排出する. Fig. 3 に示 したように，ばりが半径方向へも排出量して回転側と固定 側とが接触している圧接面が最大となった時点が初期卜ル クに到達した状態であると見なすことができるが，最も GL の距離が長い GL12 継手の場合, Fig. 13 (a) の4) の写真に示 したように試験片の最短部に該当する箇所（写真では上方 部分）が接触すらしていないため, 接合端面に傾きがない GL00 継手よりも圧接面が接触している面積が少なくなる. したがって，発生する摩擦トルクは GL00 継手よりも少な くなる。すなわち，接合端面に傾きがある場合，摩擦卜ル クが初期トルクに到達する前にすでに高温となった一部が ばりとして排出されている状態であり, 結果として初期卜 ルクが小さくなった，つまり，片当たりをともないながら 接合されたことが原因であると言える。一方，定常卜ルク は GL の増加にかかわらずほとんど変化しなかった。これ は, Fig. 13 (a)の9)の写真に示したように定常卜ルクは圧接 面の全面が接合された以降の状態であるため，接合端面に 設けた傾きは初期トルク到達までにすべて消失してしまっ たために変化しなかったと考えられる.ささらに, Fig. 16 (b) に 示した初期トルク到達時間に注目すると, GL の増加にとも なってこの時間は長くなった。これは，接合端面の傾きが 大きいほど，その傾きを完全に消失させて圧接面の全面が 接触するまでの時間が長くかかったためである。これらの 結果より，初期トルクおよび初期トルク到達時間を調べる ことで，接合時に GL の距離がどれくらいであったかを調 査できる可能性があるため，接合後でも接合端面の傾きに よる継手性能の品質管理ができると考えられる。

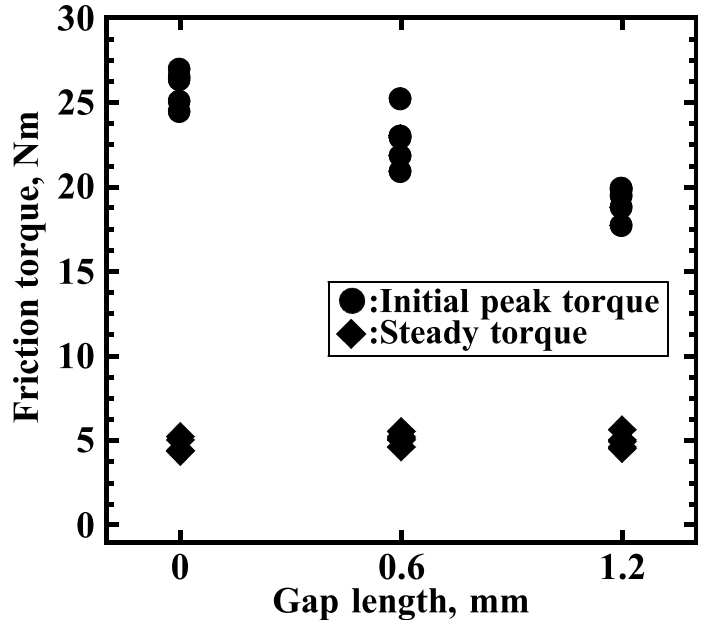

(a) Initial peak and steady torques

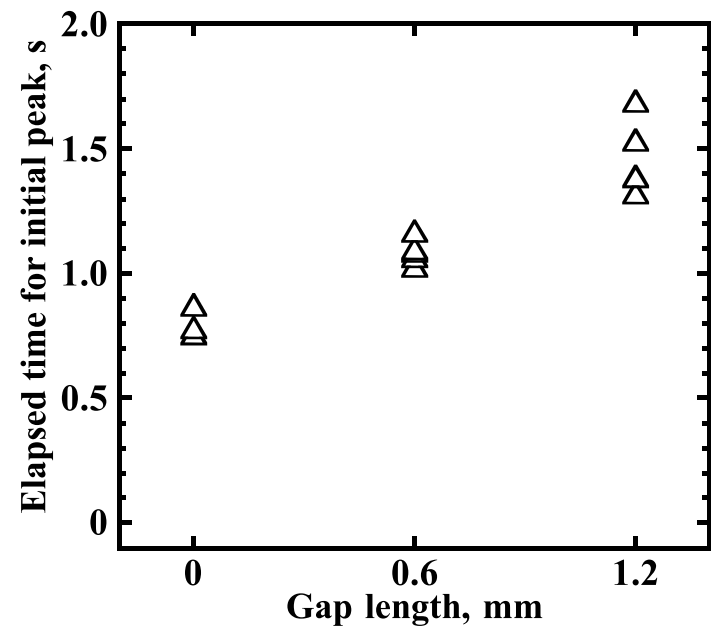

(b) Elapsed time for initial peak

Fig. 16 Effect of gap length on initial peak torque, steady torque and elapsed time for initial peak.

\section{2 継手強度の検討結果}

継手の引張試験結果について, 横軸に GL の距離を取っ て整理した結果を Fig. 17 に示す.なお, Fig. 17 は, Fig. 9, Fig. 12，Fig. 14 で示したように各傾きでアプセット圧力を $270 \mathrm{MPa}$ 付加して作製した継手について示した。（a)に示し た摩擦時間 $1.2 \mathrm{~s}$ の結果を見ると，GL00 継手，すなわち $\mathrm{GL}=0 \mathrm{~mm}$ ではすべてが $100 \%$ の継手効率を有して母材破断 した結果を示したのに対し，GL=0.6 mm（GL06 継手）では 複数本が混合破断， GL=1.2 mm (GL12 継手) ではすべてが 混合破断となり，かつ $100 \%$ の継手効率も有していない結 果となった.これは, Fig. 16 (b) に示したように, この摩擦時 間では GL00 継手は初期トルクに到達しているものの GL12 継手ではまだ到達していなく，圧接面の全面が接合されて いない状態，いわゆる接合が不十分であったためである。 また，(b) に示した摩擦時間 $1.5 \mathrm{~s}$ や (c) の $2.0 \mathrm{~s}$ の結果を見る と，GL00 継手や GL06 継手ではすべてが 100\%の継手効率 

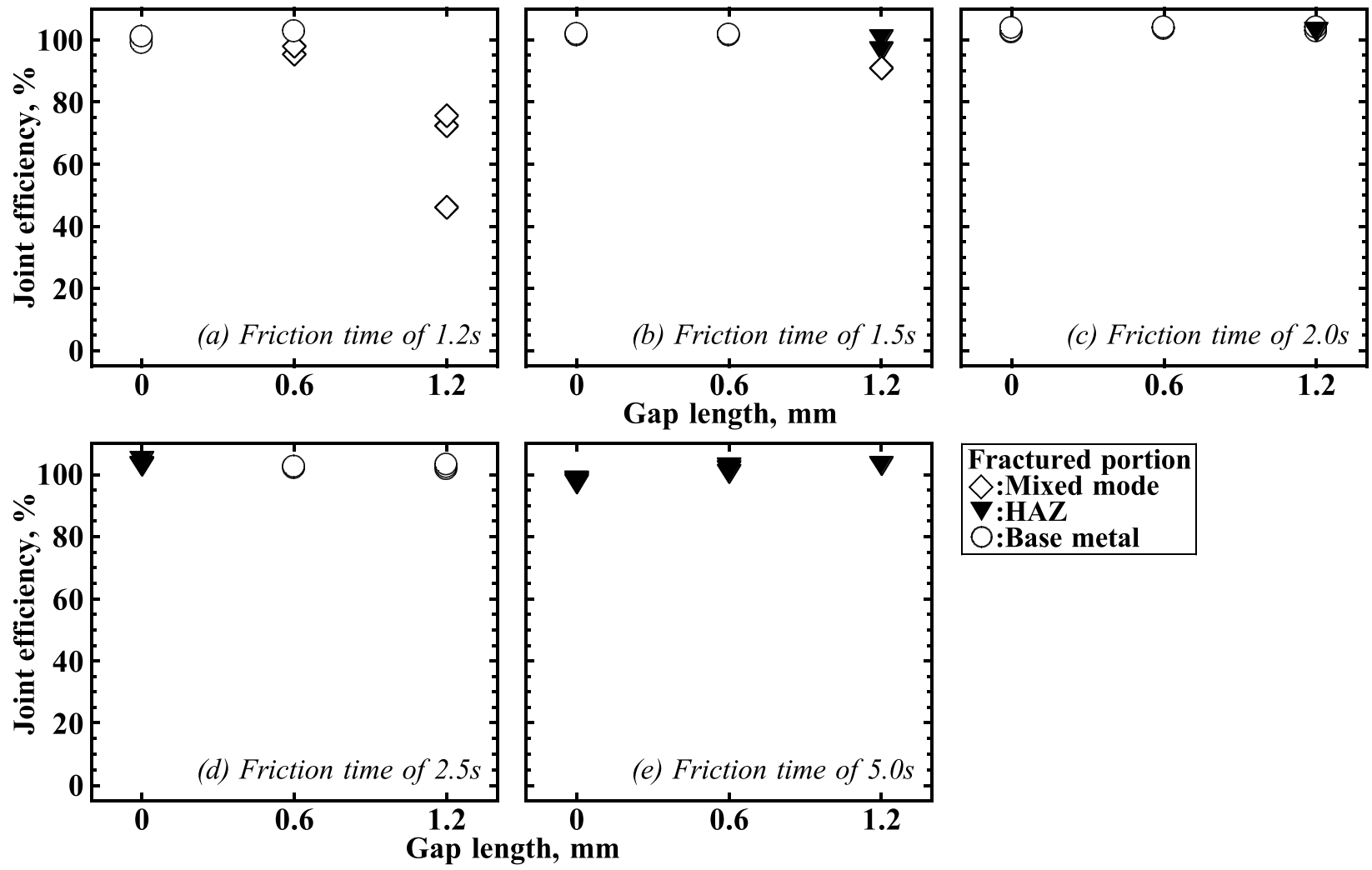

\begin{tabular}{|l|}
\hline Fractured portion \\
$\diamond:$ Mixed mode \\
$\nabla:$ HAZ \\
$\bigcirc:$ Base metal \\
\hline
\end{tabular}

Fig. 17 Relationship between gap length and joint efficiency at various friction times.

を有して母材破断したが GL12 継手ではそれは得られてお らず，これらの摩擦時間でも GL12 継手は接合が不十分で あったと言える。なお，これらの摩擦時間において，引張 試験片へと加工した後にも接合端面に傾斜を設けたことに よる圧接面に残存した未接合部がその外表面にも観察され ていたが，その圧接面半径方向の深さに関しては本研究で は測定を行っていない。一方，(d)に示した摩擦時間 $2.5 \mathrm{~s}$ の 結果を見ると，GL00 継手はHAZ 破断を呈したが，GL06 継手と GL12 継手は $100 \%$ の継手効率を有して母材破断とな っていることがわかる。これは, GL の距離が長い，つまり 接合端面の傾きが大きくなるほど圧接面の全面が完全に接 合されるまでに時間を有したことに起因している。しかし， この傾きがない GL00 継手では，この摩擦時間では摩擦熱 による入熱量が多くなりすぎたために HAZ 破断したと考え られる.さらに，(e)に示した摩擦時間 $5.0 \mathrm{~s}$ の結果を見ると， すべての継手が HAZ 破断を呈していることから，摩擦時間 が長すぎると入熱量が多くなり, 結果として接合端面の傾 きにかかわらず母材破断する良好な継手が得られなくなる こともわかった。これらの結果より，接合端面に傾きを設 けた接合試験片を用いても圧接面の全面が接触して接合さ れる状態となる以降の摩擦時間を選択することで母材部か ら破断する良好な継手を得ることはできるが，その条件で は GL00 継手は母材破断しないことがわかった.

GL00 継手と GL06 継手について, 母材破断した継手が得 られた圧接条件のうち, 摩擦時間が最短であった $1.5 \mathrm{~s}$ と
し，アプセット圧力を $270 \mathrm{MPa}$ として作製した継手の変形 能を調べた．曲げ試験を行った結果を，母材のそれとあわ せて Fig. 18 に示す.いずれの継手も，母材と同じ $90^{\circ}$ 以上の 曲がり角度が得られた。また，曲げ試験後の継手外観を見 ても，圧接面にはき裂などの欠陥は観察されなかった。こ れより，この圧接条件で作製した GL00 継手と GL06 継手 は，どちらも母材と同じく十分な曲げ延性も有しているこ とがわかった.

以上のように，本研究では，SUS304 鋼同径中害丸棒の摩 擦圧接において接合端面の傾きが継手性能に及ぼす影響を 調べた。その結果，摩擦圧力 $30 \mathrm{MPa}$ の場合，本実験の範囲 では，傾きを設けた接合端面形状であっても，圧接面の全 面が接触した後に接合された状態となる圧接条件，すなわ ち GL06 継手では摩擦時間 1.5〜2.5 s の範囲，GL12 継手で は摩擦時間 $2.5 \mathrm{~s}$ のときに, アプセット圧力 $270 \mathrm{MPa}$ を付加 することで母材破断する良好な継手が得られることがわか った。ここで，各傾きに注目すると，GL06継手拧よび GL12 継手ともに摩擦時間 $2.5 \mathrm{~s}$ では母材破断しているが, GL00 継手は Fig. 17 (d) に示したように母材破断する継手を 得られていないことがわかる。一般に，圧接条件は理想的 な接合端面形状，つまり傾きを有さない状態を基準として 選定することが望ましいため，GL12 継手が母材破断する条 件となる摩擦時間は GL00 継手が母材部から破断する摩擦 時間から外れることになる。摩擦圧力が異なると接合現象 が異なるために母材破断する継手の圧接条件も異なってく 


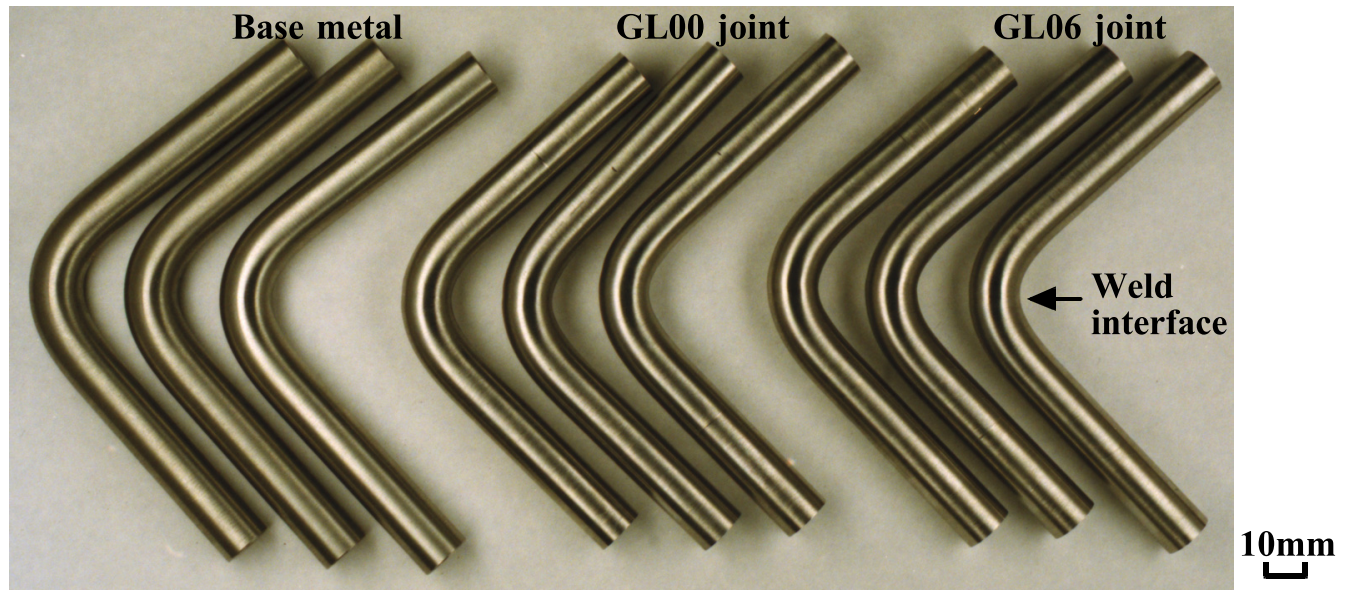

Fig. 18 Appearances of bending tested specimens for base metals and friction welded joints

るため ${ }^{16)} に$ 異なる摩擦圧力での検討を行う必要はあるが，本 研究で設定した摩擦圧力 $30 \mathrm{MPa}$ においても接合端面の傾き を変えたことにより得られる継手の引張強さに差異を生じ ている結果を踏まえると，SUS304 鋼同径中実丸棒の摩擦圧 接において許容できる接合端面の傾きは, 継手の引張試験 および継手の曲げ試験において母材と同程度の引張強さと 曲げ延性が得られる GL06 継手の傾き，すなわちJIS Z $3607^{1)}$ において炭素鋼同士で許容されている範囲を適用しな ければならないと言える。

なお，本研究では，オーステナイト系ステンレス鋼の摩 擦圧接に関し，継手性能に大きく影響を及ぼす摩擦時間と アプセット圧力に注目して検討を行ったが，摩擦速度や摩 擦圧力を変化させた場合にも圧接面の全面が接触した後に 接合された状態となったときに継手は母材部から破断する と推測することができる。また，同径丸棒同士の組み合わ せについて検討を行ったが，上述したJIS 規格1)には異径丸 棒の組み合わせやパイプを用いた場合についても記されて いる.これらの形状についても当時の経験則に基づいて決 定されたと思われるが，その詳細は不明である。したがっ て, 本研究で用いた素材や設定した圧接条件以外での接合, 上述したような形状の継手も実際の製品として用いられて いることから, それらについては今後の検討課題とさせて いただく

\section{5. 結言}

本研究では，摩擦圧接した継手の性能に及ぼす接合端面 の傾きの影響を明らかにするため，オーステナイト系ステ ンレス鋼の代表格である SUS304 の同径中実丸棒同士の組 み合わせを取り上げ，JIS Z 3607 の炭素鋼摩擦圧接の作業標 準 ${ }^{1)}$ で示されている接合端面の傾きを種々変化させて接合実 験を行って得られる継手の引張試験などを実施して接合端 面の傾きの許容限界を調べることでその影響を検討した. 得 られた知見を以下に要約する。
（1）初期トルクは，接合端面の傾きが大きくなると小さく なり，その到達時間は傾きが大きくなるともに遅くな った．しかし，定常トルクについてはほとんど差異が 認められなかった。

(2) 摩擦時間が $1.5 \mathrm{~s}$ と $2.0 \mathrm{~s}$ でアプセット圧力 $270 \mathrm{MPa}$ 付加したとき，接合端面に傾きのない GL00 継手と JIS 規格で許容されている最大の傾きを有する GL06 継手 の両方ですべが $100 \%$ の継手効率を有して母材破断と なった。

（3）摩擦時間 $2.5 \mathrm{~s}$ ，アプセット圧力 $270 \mathrm{MPa}$ のとき, GL06 継手と，JIS 規格で許容されている最大傾きの 2 倍の傾 きを有する GL12 継手の両方において，すべての継手 が 100\%の継手効率を有して母材破断となった。しか し，この圧接条件では GL00 継手は $100 \%$ の継手効率を 有しているものの HAZ 破断となった.

（4）GL00 継手，GL06 継手ともに引張試験により母材破断 する圧接条件で接合した場合，90以上の曲がり角度も 得られ，継手は十分な曲げ延性も有していることがわ かった。

（5）SUS304 鋼同径中実丸棒の摩擦圧接において許容できる 接合端面の傾きは，それがないGL00 継手と同じよう に引張りおよび曲げ試験において母材と同等の引張強 さと曲げ延性が得られた GL06 継手が有している傾き まで，すなわち JIS Z 3607 により規定されている炭素鋼 同士の組み合わせにおいて許容できる接合端面の傾き を適用しなければならない。

\section{謝辞}

本研究を遂行するにあたり，供試材料の一部を融通して いただきました（有）川上製作所川上 巧代表取締役社長に 感謝を申し上げます。また，実験装置の製作などに関して， 兵庫県立大学大学院工学研究科工作センターに御協力を頂 いたことに感謝を申し上げます。さらに，当時，熱心に実 
験に協力された兵庫県立大学 工学部 機械システム工学科 学部生の西畑彰展 君に感謝します。

\section{参 考 文 献}

1) Japanese Industrial Standards Committee: JIS Z 3607 Recommended practice for friction welding of carbon steel, (1994). (in Japanese)

2) K. Katoh, H. Tokisue: Effect of inclination angle of faying surface on the mechanical properties of friction welded joints of 5052 aluminum alloy, Journal of Japan Institute of Light Metals, 49-11 (1999), 553-558. (in Japanese)

3) M. Kimura, H. Mioh, M. Kusaka, K. Seo, A. Fuji: Observation of the Joining Phenomena in First Phase of Friction Welding - Study of Joining Mechanism of Friction Welding (Report 1) -, Quarterly Journal of the Japan Welding Society, 20-4 (2002), 559-565. (in Japanese)

4) K. Okita, W. Kishimoto: Studies on Friction Welding of SUS 304 Austenitic Stainless (Report 1) - Charpy Absorbed Energy of Friction Welded Joint -, Journal of the Japan Welding Society, 4811 (1979), 991-995. (in Japanese)

5) A. Ishibashi, S. Ezoe, S. Tanaka: Studies on Friction Welding of Carbon and Alloy Steels: 3rd Report, Adequate Welding Conditions for High Alloy Steels and Distribution of Alloy Elements near Weld Interface, Transactions of the Japan Society of Mechanical Engineers: C, 48-434 (1982), 1588-1597. (in Japanese)

6) H. Nakayama, K. Ohhira, K. Okita, M. Aritoshi, A. Hasui: Fatigue Strength Characteristics and Fractographic Features of SUS 304/SUS 304 Friction Welded Butt Joint, Journal of The Society of Materials Science, Japan, 33-367 (1984), 447-453. (in Japanese)

7) K. Ogawa, H. Yamaguchi, G. Kawai, T. Sawai: Selection of Optimum Welding Condition and Evaluation of Joint Performance Using Friction Welding Behaviours, Quarterly Journal of the Japan Welding Society, 16-1 (1998), 18-24. (in Japanese)

8) P. Sathiya, S. Aravindan, A. N. Haq: Mechanical and metallurgical properties of friction welded AISI 304 austenitic stainless steel, International Journal of Advanced Manufacturing Technology, 26 (2005), 505-511.

9) M. Sahin: Evaluation of the joint-interface properties of austeniticstainless steels (AISI 304) joined by friction welding, Materials and Design, 28 (2007), 2244-2250.

10) G. M. Reddy, K. S. Rao: Microstructure and mechanical properties of similar and dissimilar stainless steel electron beam and friction welds, International Journal of Advanced Manufacturing Technology, 45 (2009), 875-888.

11) M. Hasegawa, R. Kaku: Fatigue Properties of Friction Welded Joints with Flash by Austenitic Stainless steel and Various Carbon Steels for Machine Structural, Quarterly Journal of the Japan Welding Society, 28-4 (2010), 355-361. (in Japanese)

12) M. V. Kumar, V. Balasubramanian: Microstructure and tensile properties of friction welded SUS $304 \mathrm{HCu}$ austenitic stainless steel tubes, International Journal of Pressure Vessels and Piping, 113 (2014), 25-31.

13) M. Kimura, M. Kusaka, K. Seo, A. Fuji: Relationship between the Friction Time, Friction Torque, and Joint Properties of Friction Welding for the Low Heat Input Friction Welding Method - Study of Joining Mechanism of Friction Welding (Report 3) -, Quarterly Journal of the Japan Welding Society, 20-4 (2002), 559-565. (in Japanese)

14) A. Hasui, S. Fukushima: On the Torque in Friction Welding, Journal of the Japan Welding Society, 44-12 (1975), 1005-1010. (in Japanese)

15) M. Kimura, M. Kusaka, K. Seo, A. Fuji: Joining phenomena during friction stage of A7075-T6 aluminum alloy friction weld, Science and Technology of Welding and Joining, 10-3 (2005), 378-383.

16) M. Kimura, Y. Ohtsuka, G. B. An, M. Kusaka, K. Seo, A. Fuji: Effect of Friction Speed on Initial Seizure Portion on Welded Interface - Study of joining mechanism of friction welding (Report 4) -, Quarterly Journal of the Japan Welding Society, 21-4 (2003), 615-622. (in Japanese) 